\title{
Studi Struktur dan Pertumbuhan Populasi Kerang Pokea (Batissa violacea var. celebensis, von Martens 1897) di Sungai Pohara Sulawesi Tenggara
}

\section{(Structure and Growth Population of Pokea Clam (Batissa violacea var. celebensis, von Martens 1897) in Pohara River on Southeast Sulawesi)}

\author{
Bahtiar $^{1}$, Hamzah, $\mathrm{M}^{1}$. dan Hari, $\mathrm{H}^{1}$. \\ ${ }^{1}$ Dosen Fakultas Perikanan dan Ilmu Kelautan UHO
}

\begin{abstract}
ABSTRAK
Pokea merupakan bivalvia air tawar yang hidup di segmen muara. Bivalvia ini terus mengalami tekanan sejalan dengan peningkatan aktivitas kegiatan penangkapan dan menurunnya kualitas perairan. Penelitian ini bertujuan untuk mengetahui struktur dan pertumbuhan populasi kerang pokea di Sungai Pohara Sulawesi Tenggara. Penelitian ini dilaksanakan di segmen muara Sungai Pohara selama setahun dari bulan Maret 2007-Februari 2008. Parameter populasi ( $\mathrm{L} \infty$ dan $\mathrm{K}$ ) dan to masing-masing dianalisis dengan menggunakan pergerakan modus frekuensi panjang dan nilai $\mathrm{L} 0=0.025$. Pola pertumbuhan dianalisis menggunakan inverse von Bertalanffy sedangkan struktur populasi dianalisis menggunakan distribusi normal dari plot Bhattacharya yang secara keseluruhan terakomodasi pada program FiSAT II versi 3.0. Hasil penelitian menunjukkan bahwa lebar asimtotik dan koefisien pertumbuhan jantan dan betina masing-masing yaitu $7.16 \mathrm{~cm}, 0.59$ dan $6.92 \mathrm{~cm}, 0.96$. Oleh karenai tu, pertumbuhan pokea betina lebih cepat dibandingkan pokea jantan. Populasi kerang pokea tersebar pada berbagai kelompok ukuran yang mewakili ukuran muda, dewasa dan tua dengan nilai tengah berada pada 1.49 dan 6.01 yang menyebar pada tiga kelompok ukuran. Kelompok ukuran dominan pada jantan betina relatif berbeda yang tersebar pada nilai tengah masing-masing $1 \mathrm{~cm}$ dan $2 \mathrm{~cm}$. Secara umum, struktur populasi pokea di Sungai Pohara relatif stabil.

Kata kunci : pokea, pertumbuhan, struktur, populasi, sungai, Pohara
\end{abstract}

\begin{abstract}
Pokea clam was fresh water bivalve that lived on well into estuary segments. This bivalve have experienced in under pressure as activity increase in fishing events and decrease in water quality. This research aimed to understand the structure and growth population of pokea clam in Pohara river on Southeast Sulawesi. This research was conducted in estuary segment of Pohara river from March 2007 to February 2008. Parameters of population (L $\infty$ dan $\mathrm{K}$ ) and $\mathrm{t}_{\mathrm{o}}$ were analyzed by using movements in modus of length frequency and Lo $=0.025$. Growth pattern was analyzed by using von Bertalanffy inverse, and population structure was analyzed by using normal distribution from Bhattacharya plot with full accommodation on FiSAT II version 3.0. The results of this research indicated that asymptotic width and growth coefficient for male and female were $7.16 \mathrm{~cm}, 0.59 \mathrm{~cm}$, and $0.96 \mathrm{~cm}$. Therefore, the growth of female pokea was faster than male. Pokea clam population spread to several size groups that represented as young, adult, and old with median 1.49 and 6.01. The dominant length measurement on male and female was relatively different which propagated in median $1 \mathrm{~cm}$ and $2 \mathrm{~cm}$. Generally, population structure of pokea clam in Pohara river was relatively stable.
\end{abstract}

Keyword: pokea, growth, structure, population, river, Pohara 


\section{PENDAHULUAN}

Sungai Pohara merupakan salah satu sungai yang mengalir sepanjang tahun (permanen) di Sulawesi Tenggara. Sungai ini menyimpan potensi sumberdaya hayati diantaranya adalah jenis kerang air tawar yang masyarakat sekitarnya menyebutnya dengan nama pokea (Batissa violacea var. celebensis, von Martens 1897). Kerang ini tersebar merata pada sungai besar lain di daerah ini seperti Sungai Lasolo (Konawe Utara), Sungai Roraya, Sungai Laeya dan Sungai (Konawe Selatan), Sungai Langkumbe dan Sungai Lambale (Buton Utara) serta beberapa sungai lain yang belum terekam (Bahtiaret al., 2014).

Kerang pokea telah lama dimanfaatkan sebagai bahan makanan oleh masyarakat Konawe. Permintaan masyarakat akan daging kerang pokea yang terus meningkat maka sebagian masyarakat (nelayan) telah mengusahakannya dengan mengambilnya di alam sehingga menjadi mata pencaharian utama dari masyarakat tersebut. Berdasarkan hasil penelitian Bahtiar (2012) menunjukkan bahwa produksi kerang pokea yang didaratkan di Pasar Pohara dalam setahun dapat mencapai $152879 \mathrm{~kg}$ berat basah. Namun tidak diketahui secara pasti besarnya produksi total pokea yang hilang di setiap tahunnya, karena banyaknya tempat pendaratan lain yang tidak terekam. Pengambilan pokea yang dilakukan secara terus menerus akan memberikan pengaruh pada struktur populasi kerang pokea di alam. Bila pertumbuhan populasi tidak dapat mengimbangi laju kematian karena penangkapan maka akan menyebabkan adanya lebih tangkap yang ditandai dengan banyaknya pokea yang berukuran kecil.

Pada sisi lain, pertumbuhan dan struktur populasi kerang pokea belum diketahui secara pasti sedangkan hal tersebut sangat penting untuk mengetahui kestabilan populasi bagi tujuan pengelolaan sumberdaya kerang pokea di alam. Oleh karena itu, perlu dilakukan penelitian tentang studi struktur pertumbuhan dan pertumbuhan kerang pokea di Sungai Pohara Sulawesi Tenggara. Penelitian ini bertujuan untuk mengetahui struktur dan pertumbuhan populasi kerang pokea di Sungai Pohara Sulawesi Tenggara. Penelitian ini diharapkan dapat bermanfaat bagi pengelolaan sumberdaya kerang pokea di Sungai Pohara dan menjadi rujukan pengelolaan sumberdaya kerang di Sulawesi Tenggara.

\section{BAHAN DAN METODE}

Penelitian ini dilaksanakan selama setahun dari bulan Maret 2007-Februari 2008 di segmen muara Sungai Pohara (Gambar 1). Sampel pokea dikumpulkan dengan melakukan sapuan alat tangkap tangge (alat tangkap tradisional) di dasar perairan. Sampel dikumpulkan pada seluruh bagian sungai di seluruh segmen muara dari awal, pertengahan dan akhir ditemukan pokea pada 6 titik pengamatan. Jumlah sampel yang terambil di setiap stasiun dalam setiap bulan berkisar 450-750 ekor yang berasal dari semua kelas ukuran, sehingga total sampel yang terkumpul sebanyak 7100 ekor. Selanjutnya kerang dibawa ke Laboratorium Perikanan dan Ilmu Kelautan Unhalu untuk dilakukan pengamatan dan pengukuran lebar cangkang. Pokea diukur lebar cangkangnya dengan menggunakan jangka sorong dengan ketelitian $0.01 \mathrm{~mm}$. Selanjutnya membuka cangkangnya untuk membedakan pokea jantan dan betina berdasarkan warna gonadnya. Jantan mempunyai warna gonad 


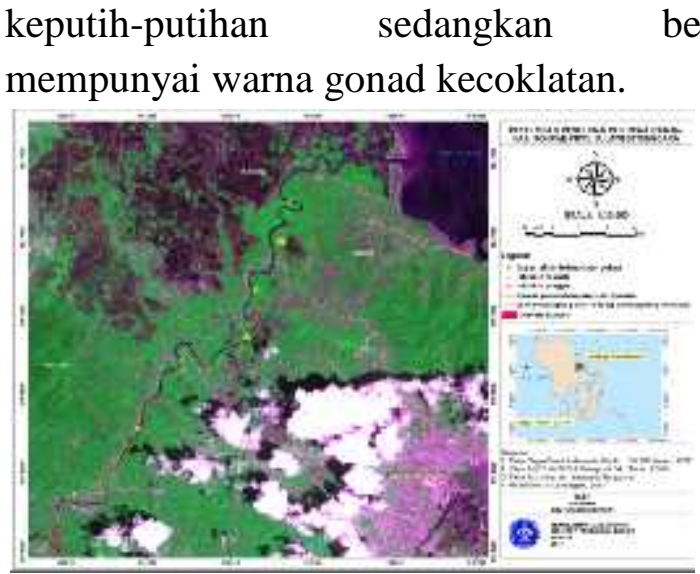

Gambar 1. Peta penelitian kerang pokea di Sungai Pohara

Analisis data strruktur populasi kerang pokea dianalisis dengan melakukan pemisahan kelompok-kelompok umur pokea berdasarkan ukuran lebar cangkangdengan menggunakan metode Bhattacharya. Metode Bhattacharya merupakan salah satu grafis untuk memisahkan data sebaran frekuensi lebar cangkang ke dalam beberapa distribusi normal.Pemisahan distribusi normal dengan metode Bhattacharya ini dilakukan dengan bantuan paket program FiSAT (Gayanilo dan Pauly, 2002). Pendugaan koefisien pertumbuhan $(K)$ dan panjang infiniti $(\mathrm{L} \infty)$ dilakukan dengan menggunakan ELEFAN pada paket program FiSAT(Gayanilo dan Pauly, 2002). Parameter pertumbuhan to atau Lo ditentukan berdasarkan nilai diameter telur pokea yang yang berkisar 0.01-0.3 mm sehingga Lo berada pada nilai tengah $0.025 \mathrm{~mm}$ (Bahtiar, 2012). Pola pertumbuhan panjang cangkang jantan dan betina ( $\mathrm{Lt}$ ) pada umur tertentu ( $\mathrm{t}$ ) dihitung dengan persamaan inverse von Bertalanffy seperti yang disarankan oleh (Bretos, 1980; Hughes dan Roberts, 1980; Narismham, 1981; dan Anthony, 2001) yaitu :

$$
\mathrm{Lt}=\mathrm{L} \infty-(\mathrm{L} \infty-\mathrm{LO}) \mathrm{e}^{-\mathrm{Kt}}
$$

\section{Keterangan :}

$\mathrm{Lt}=$ panjang ikan pada saat berumur $\mathrm{t}$
$\mathrm{L} \infty=$ panjang ikan infinity atau asimptotik

$\mathrm{L} 0=$ panjang ikan pada saat berumur 0

$\mathrm{K}=$ koefisien pertumbuhan

$\mathrm{t}=$ umur ikan

\section{HASIL DAN PEMBAHASAN}

\section{Pertumbuhan Populasi}

Hasil penelitian menunjukkan bahwa parameter pertumbuhan pokea jantan dan betina relatif berbeda. Lebar asimtotikpokea jantan dan betina masing-masing yaitu 7.16 $\mathrm{cm}$, dan $6.92 \mathrm{~cm}$. Koefisien pertumbuhan jantan dan betina masing-masing yaitu dengan koefisien pertumbuhan 0.59 dan 0.96 (Tabel 1). Oleh karena itu, populasi pokea betina lebih cepat mencapai L infinity dan mempunyai pertumbuhan yang lebih cepat dibanding jantan dengan proporsi waktu pada jantan dan betinamasing-masing sebesar 28 bulan dan 17 bulan (Gambar 2).

Tabel 1. Parameter pertumbuhan kerang pokea di Sungai Pohara

\begin{tabular}{|c|c|c|c|}
\hline \multirow{2}{*}{ No. } & \multirow{2}{*}{ Jenis Kelamin } & \multicolumn{2}{|c|}{$\begin{array}{c}\text { Parameter } \\
\text { Pertumbuhan }\end{array}$} \\
\cline { 3 - 4 } & & L $\infty$ & K \\
\hline 1. & Jantan & 7.16 & 0.59 \\
\hline 2. & Betina & 6.92 & 0.96 \\
\hline
\end{tabular}

Panjang asimtotik yang digunakan adalah lebar pokea merujuk pada King (1997) dan Spare dan Venema (1998) bahwa kerang yang mempunyai ukuran lebar lebih besar daripada panjang, maka ukuran panjang digantikan dengan ukuran lebar. Persamaan pertumbuhan jantan dan betina masing-masing : $\mathrm{Lt}=7.16-(7.16-$ $0.025) \mathrm{e}^{-0.59 \mathrm{t}}$ dan $\mathrm{Lt}=6.92-(6.92-0.025) \mathrm{e}^{-}$ ${ }^{0.96 t}$.Berdasarkan hasil penelitian menunjukkan bahwa panjang asimtotik (lebar) pokea jantan lebih besar 
dibandingkan betina namun kofisien pertumbuhan pada jantan lebih kecil dibanding betina. Oleh karena itu, jantan mempunyai pertumbuhan yang lebih lambat dibanding betina dalam mencapai panjang maksimun. Namun pertumbuhan populasi tidak selamanya memperlihatkan bahwa betina mempunyai pertumbuhan lebih cepat dibanding jantan. Hal ini ditunjukkan oleh penelitian Bahtiar (2012), dan Bahtiar, et al., (2014) bahwa jantan mempunyai pola pertumbuhan populasi lebih cepat dibanding betina dalam mencapai $\mathrm{L} \infty$. Demikian pula pertumbuhan beberapa jenis kerang lain yang memperlihatkan tidak menentunya kecepatan pertumbuhan berdasarkan jenis kelamin. Pada jenis Polymesoda erosa menunjukkan bahwa betina lebih cepat dibanding jantan, sebaliknya Perna viridis memperlihatkan bahwa jantan tumbuh lebih cepat dibanding betina (Tabel 2). Pola yang tidak beraturan dari pertumbuhan populasi pokea pada kerang jantan dan betina dan beberapa jenis lainnya belum diketahui secara pasti.

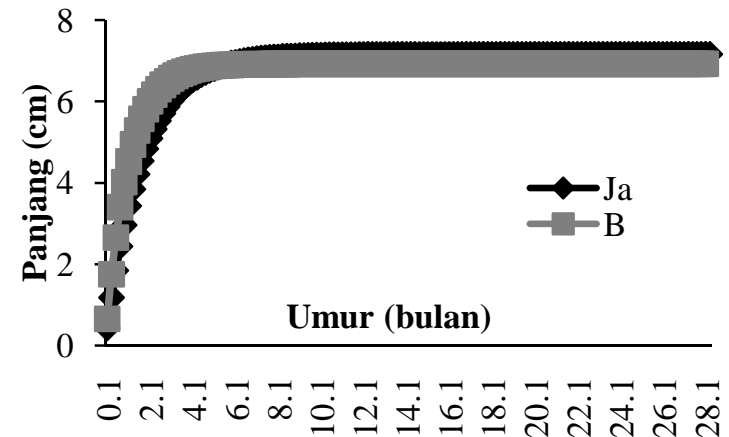

Gambar 2.Kurva pertumbuhan von Bertalanffy berdasarkan data frekuensi panjang pokea.

Secara umum, pertumbuhan kerang pokea lebih cepat dibandingkan Polymesoda acutidens, Polymesoda erosa, dan Perna viridis namun tidak secepat pertumbuhan Anodonta edentula. Demikian halnya dengan nilai pertumbuhan dari beberapa jenis bivalvia tawar unionidae lainnya yang lebih rendah dibandingkan keranga pokea yang ditunjukkan dengan nilai $\mathrm{L} \infty$ dan $\mathrm{K}$ dari beberapa jenis bivalvia seperti Elliptio complanata dengan nilai masing-masing sebesar 7.40 dan 0.176; Lampsilis siliquoidea sebesar 13.0 dan 0.05; serta Pyganodon grandis sebesar 11.20 dan 0.032 (Anthony, et al. 2001).

Tabel 2. Parameter pertumbuhan kerang berbagai perairan di Indonesia

\begin{tabular}{|l|l|l|l|l|ll|}
\hline Lokasi & \multicolumn{1}{|c|}{ Spesies } & Jenis Kelamin & K & L $\infty$ & Sumber \\
\hline $\begin{array}{l}\text { Sungai Lasolo Sulawesi } \\
\text { Tenggara }\end{array}$ & B.violacea & $0^{\star}$ & 1.2 & 7.36 & Bahtiaret al., \\
& & $\circ$ & 0.63 & 7.88 & 2014 & \\
\hline Teluk Kendari Sulawesi & P. erosa & gabungan ơ $q$ & 0.71 & 9.62 & Safaat, 2014 \\
\hline
\end{tabular}




\begin{tabular}{|c|c|c|c|c|c|}
\hline Tenggara & & & & & \\
\hline $\begin{array}{l}\text { Sungai Pohara Sulawesi } \\
\text { Tenggara }\end{array}$ & B.violacea & $\begin{array}{l}0^{\pi} \\
+\end{array}$ & $\begin{array}{l}0.71 \\
0.91\end{array}$ & $\begin{array}{l}7.84 \\
8.94\end{array}$ & Bahtiar, 2012 \\
\hline Dumai Riau & P. acutidens & gabungan $\sigma^{x}+9$ & 0.59 & 9.27 & Efriyeldi, 2012 \\
\hline $\begin{array}{l}\text { Teluk Kendari Sulawesi } \\
\text { Tenggara }\end{array}$ & P. erosa & $\begin{array}{l}0^{\pi} \\
+\end{array}$ & $\begin{array}{l}0.57 \\
0.92\end{array}$ & $\begin{array}{l}9.85 \\
8.77\end{array}$ & Tamsar, 2012 \\
\hline $\begin{array}{l}\text { Sorue Jaya Sulawesi } \\
\text { Tenggara }\end{array}$ & P.viridis & $\begin{array}{l}0 \\
0\end{array}$ & $\begin{array}{l}1.2 \\
0.74\end{array}$ & $\begin{array}{l}8.4 \\
8.93\end{array}$ & Hasa, 2008 \\
\hline Teluk Ambon & A. edentula & gabungan $\sigma^{x}+9$ & 1.5 & 7.06 & Natan, 2008 \\
\hline Sungai Pohara (alamiah) & B. violacea & gabungan $\sigma^{\top}$ ㅇ & 0.87 & 6.59 & Bahtiar, 2005 \\
\hline $\begin{array}{l}\text { Sungai Pohara } \\
\text { (penambangan pasir) }\end{array}$ & B. violacea & gabungan $\delta^{x} P$ & 0.44 & 4.79 & Bahtiar, 2005 \\
\hline
\end{tabular}

Keterangan :

$$
\begin{aligned}
& \mathrm{K}=\text { koefisien pertumbuhan } \\
& \mathrm{L} \infty=\text { panjang infinity }
\end{aligned}
$$

\section{Struktur Populasi}

Pokea jantan dan betina tersebar dari kelompok ukuran dengan nilai tengah lebar masing-masing yaitu $1.55-6.01 \mathrm{~cm}$ dan 2.06 - $5.98 \mathrm{~cm} . J u m l a h$ populasi kerang pokea jantan tersebar didominasi oleh kelompok ukuran 1.73-2.87, sedangkan pada ukuran lebih besar 3.05 berada pada jumlah populasi yang lebih sedikit bahkan tidak ditemukan pada bulan tertentu. Tidak berbeda dengan betina, jumlah populasi kerang terbesar ditemukan pada kelompok ukuran 2.0, namun pada kelompok ukuran 3.0 masih ditemukan cukup pada beberapa bulan tertentu. Baik jantan dan betina, kelompok ukuran di atas 4.0 hampir tidak ditemukan lagi di Sungai Pohara (sangat jarang). Kelompok ukuran pokea betina dan jantan didominasi 2 kelompok ukuran di setiap bulannya (Tabel 3).
Tabel 3. Kelompok ukuran kerang pokea di Sungai Pohara

\begin{tabular}{|l|c|c|c|c|c|c|}
\hline \multirow{3}{*}{ Bulan } & \multicolumn{5}{|c|}{ Kelompok ukuran (mm) } \\
\cline { 2 - 8 } & \multicolumn{3}{|c|}{ Jantan } & \multicolumn{3}{c|}{ Betina } \\
\cline { 2 - 8 } & I & II & III & I & II & III \\
\hline Maret & 2.63 & 5.90 & - & 3.18 & 5.78 & - \\
\hline April & 2.87 & 6.01 & - & 3.43 & 5.98 & - \\
\hline Mei & 2.34 & - & - & 2.63 & - & - \\
\hline Juni & 1.73 & 3.23 & - & 2.27 & 3.51 & 4.61 \\
\hline Juli & 1.49 & 3.26 & - & 2.19 & 3.74 & - \\
\hline Agustus & 1.55 & - & - & 2.12 & 3.40 & - \\
\hline September & 1.73 & 3.05 & - & 2.06 & 3.52 & - \\
\hline Oktober & 1.92 & 3.29 & - & 2.16 & 3.36 & - \\
\hline November & 2.20 & 3.27 & 4.29 & 2.42 & - & - \\
\hline Desember & 2.13 & 3.57 & - & 2.37 & 3.93 & - \\
\hline Januari & 2.31 & 3.37 & - & 2.24 & - & - \\
\hline Februari & 2.13 & - & - & 2.24 & - & - \\
\hline
\end{tabular}

Keterangan : - tidak ada kelompok ukuran

Berdasarkan pengamatan menunjukkan bahwa kelompok ukuran kerang mengalami pergeseran di setiap 
bulannya. Pada jantan menunjukkan pergeseran ke arah kanan pada bulan Maret April, Juli - November dan Desember Januari sedangkan pergeseran ke arah kiri terjadi pada bulan April - Juli, November Desember dan Januari - Februari. Pergeseran kelompok ukuran pada betina ke arah kanan terjadi pada bulan Maret - April dan September - November, sedangkan pergeseran ke arah kiri terjadi pada bulan

\section{Jantan}
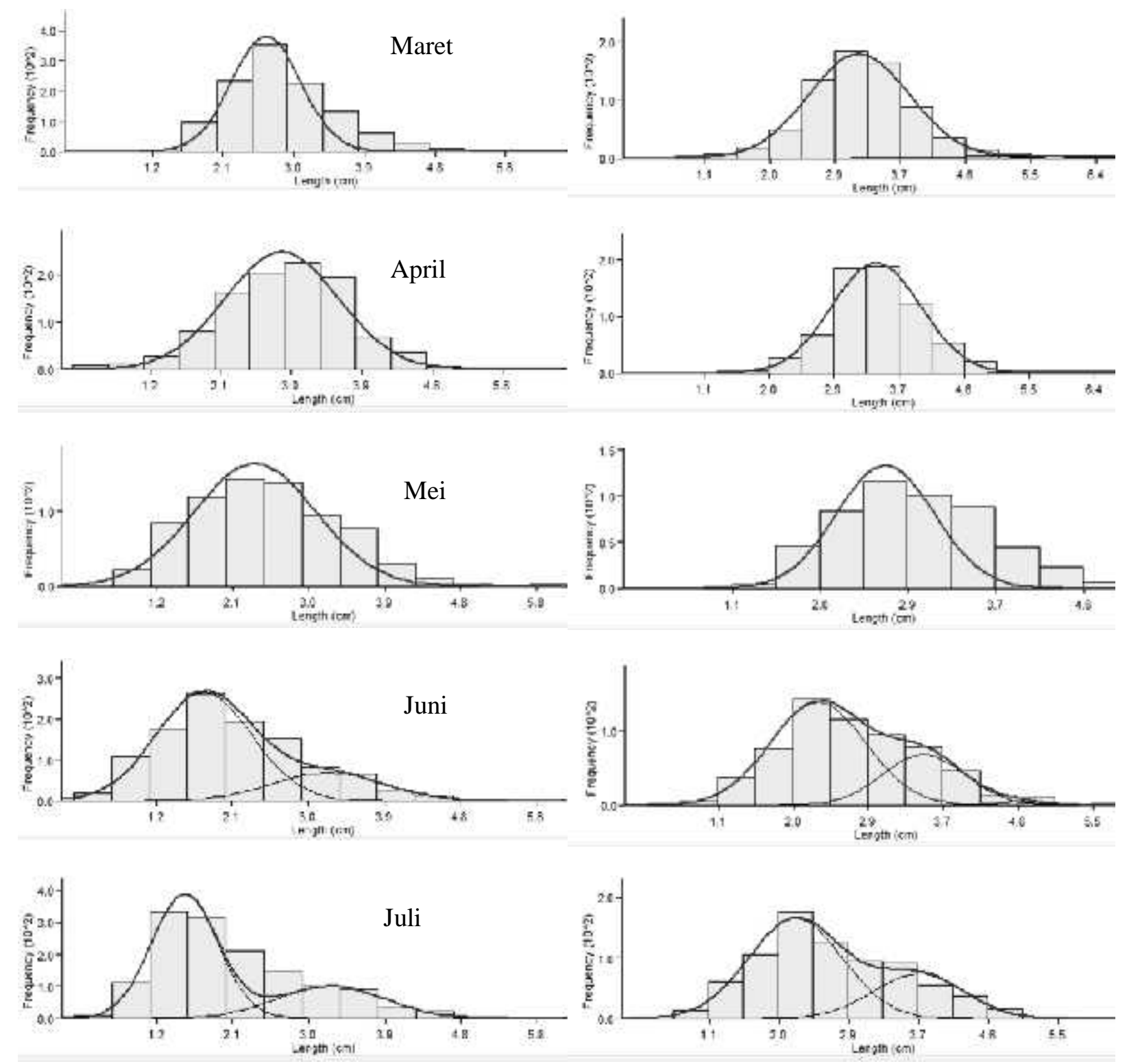

April - September dan November - Januari (Gambar 3)

\section{Betina}
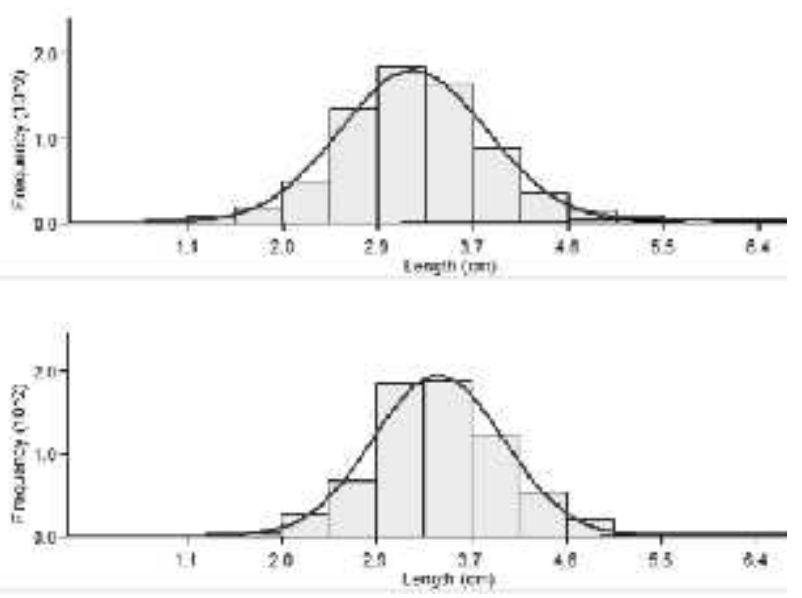

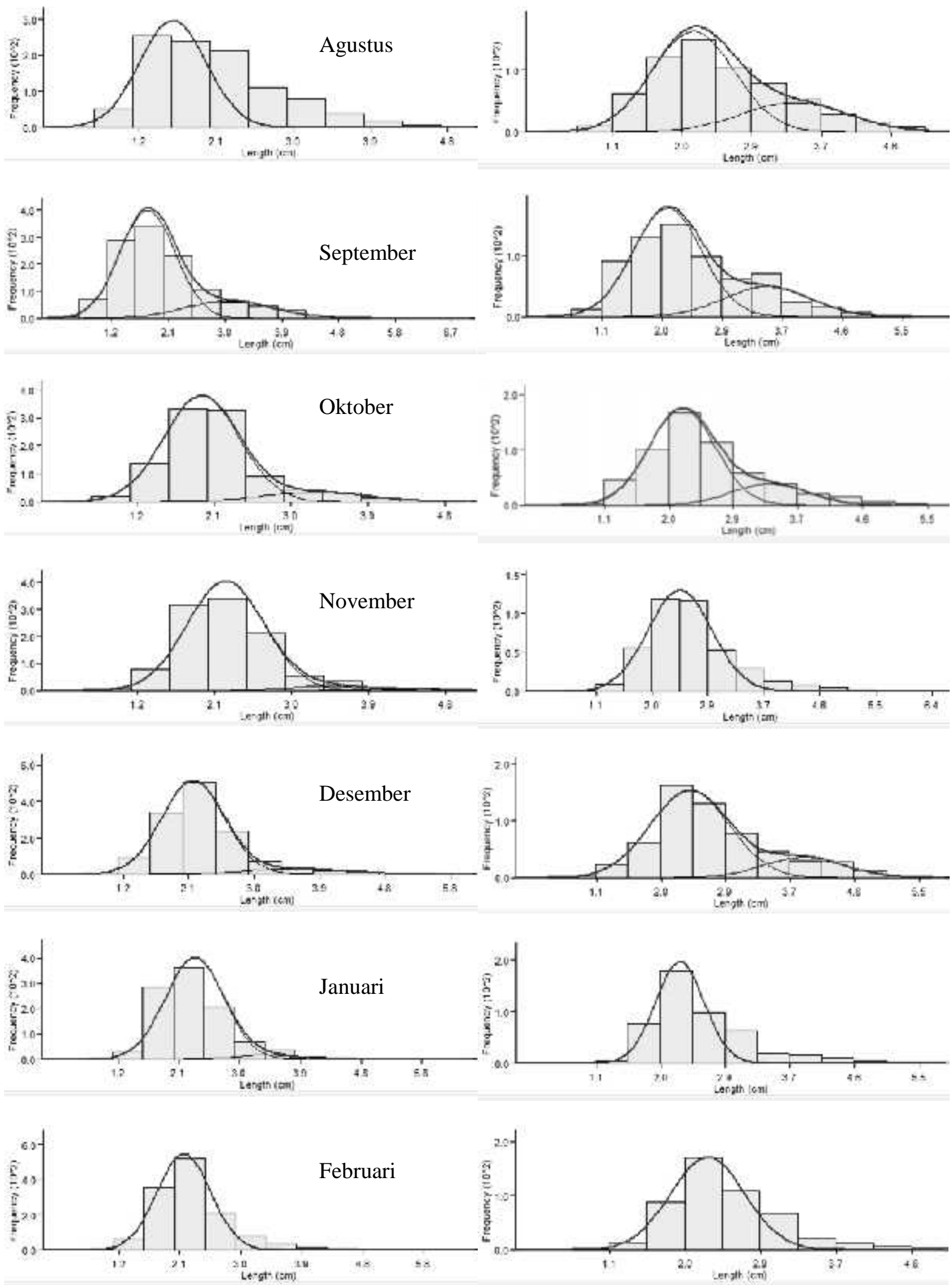

Gambar 3. Kelompok ukuran kerang pokea jantan dan betina di setiap bulannya

Kelompok ukuran yang terbentuk panjang/lebar dianggap sebagai sebagai dari sekumpulan data frekuensi suatu kelompok (kohort) yang tumbuh 
berkembang dan mengalami proses yang sama atau dengan kata lain kelompok yang dianggap mempunyai umur yang sama. Sebaran frekuensi yang berada pada satu kelompok dan menyebar secara normal dianggap sebagai satu kelompok ukuran. Bhatacharya mengembangkan pola ini dengan memanfaatkan pola sebaran frekuensi. Data frekuensi lebar pokea dianalisis berdasarkan metode modal progression methodBhattacharya untuk mendapatkan kelompok ukuran dengan bantuan perangkat lunak program FiSAT. Kelompok ukuran tersebut dapat dijadikan sebagai rujukan dalam mengamati struktur populasi kerang pokea di Sungai Pohara.

Pokea jantan dan betina tersebar dari kelompok ukuran dengan nilai tengah lebar masing-masing yaitu $1.55-6.01 \mathrm{~cm}$ dan 2.06 - 5.98 cm.Jumlah populasi kerang pokea jantan tersebar didominasi oleh kelompok ukuran 1.73-2.87, sedangkan pada ukuran lebih besar 3.05 berada pada jumlah populasi yang lebih sedikit bahkan tidak ditemukan pada bulan tertentu. Tidak berbeda dengan betina, jumlah populasi kerang terbesar ditemukan pada kelompok ukuran 2.0, namun pada kelompok ukuran 3.0 masih ditemukan cukup pada beberapa bulan tertentu. Baik jantan dan betina, kelompok ukuran di atas 4.0 hampir tidak ditemukan lagi di Sungai Pohara (sangat jarang). Kelompok ukuran pokea betina dan jantan didominasi 2 kelompok ukuran di setiap bulannya (Tabel 3).

Secara umum, kelompok ukuran pokea tersebar dari ukuran anak, dewasa dan tua. Kelompok ukuran pokea jantan didominasi ukuran anak dan awal pertama kali matang gonad (remaja). Hal ini ditegaskan pada beberapa penelitian menunjukkan bahwa kerang pokea mengawali matang gonad pada ukuran 2.1 dan $2.3 \mathrm{~cm}$ (Bahtiar, 2007, 2012) yang merupakan peralihan pada fase anak ke remaja/dewasa. Kelompok ukuran anak dan remaja sangat dominan dibandingkan dengan ukuran tua yang ditemukan dalam jumlah yang sangat sedikit. Hal ini menyebabkan rentannya kondisi populasi karena ukuran ini merupakan ukuran yang sering ditangkap terutama pada populasi pokea yang hanya mempunyai 1 kelompok ukuran populasi yang didominasi ukuran anak atau dewasa (1 generasi) pada bulan-bulan tertentu (Mei, Agustus, November, Januari dan Februari). Hilangnya kelompok ukuran ini disebabkan oleh tingginya intensitas penangkapan pada bulan tersebut. Aktivitas penangkapan yang dilakukan masyarakat terjadi pada bulan Mei-November . Hal ini didasarkan pada aktivitas pematangan gonad yang terjadi 2 kali yaitu kematangan puncak di bulan Agustus-September, dan Januari (Bahtiar, 2012). Kelompok ukuran tua hampir tidak ditemukan lagi di Sungai Pohara. Hal ini mengindikasikan tingginya eksploitasi kerang pokea. Hal ini dapat dibuktikan dari nilai tingkat pemanfaatan yang berada di atas dari 0.5 setiap saat (Bahtiar, 2007 dan 2012). Walaupun demikian, secara umum memperlihatkan bahwa struktur populasi pokea di Sungai Pohara masih relatif stabil dengan ditemukannya dominansi 2 kelompok ukuran di setiap bulannya yang tersebar pada kelompok anak, dewasa dan tua di setiap bulannya. Kisaran ukuran dan jumlah generasi ini tidak berbeda jauh dengan penelitian Puteri (2005) yang didominasi pada kisaran panjang 2.2-2.7 $\mathrm{cm}$ (lebar $\pm 2.7-3.1 \mathrm{~cm}$ ) dengan 2-3 generasi dan Bahtiar et al., (2008) yang berada pada ukuran 3.19-4.26 dengan 1-3 generasi.

Pergeseran kelompok ukuran pada populasi kerang menggambarkan adanya dinamika dalam populasi kerang. Pergeseran ke arah kanan pada kelompok ukuran mengindikasikan bahwa adanya 
peningkatan kelas ukuran sebagai akibat dari pertumbuhan populasi (panjang dan berat), sedangkan pergeseran ke arah kiri pada kelompok ukuran mengindikasikan adanya rekrutmen baru dalam populasi. Rekrutmen yang terjadi dan ditemukan hampir setiap bulan sebagai akibat dari 1) pemijahan kerang pokea terjadi setiap saat (partial spawner), walaupun mempunyai 2 fase puncak pemijahan yang terjadi pada akhir bulan Juli dan November (Bahtiar, 2012) dan 2) keberhasilan pemijahan dan lengkapnya siklus awal daur hidup kerang pokea yang telah menjadi hewan bentos (tipe d).

\section{Kesimpulan}

Berdasarkan hasil dan pembahasan maka dapat ditarik kesimpulan sebagai berikut : 1) pertumbuhan jantan lebih lambat dibandingkan betinadan 2) struktur populasi pokea di Sungai Pohara masih relatif stabil yang menyebar dari stadia anak, dewasa dan tua.

\section{Ucapan Terima Kasih}

Terima kasih banyak diucapkan kepada mahasiswa dan tim lapangan yang telah membantu terselenggaranya penelitian ini diantaranya Anton, Zul, Mila, Wati, Tia, Ana, Kartini,dan Fitriani.

\section{Daftar Pustaka}

Anthony, J.L, D.H. Kesler, W. L. Downing and J.A. Downing,. 2001. LengthSpecific Growth Rates in Freshwater Mussels (Bivalvia: Unionidae): Extreme Longevity or Generalized Growth Cessation?. J. Freshwater Biology. 46: 1349-1359.

Bahtiar. 2005. Kajian Populasi Pokea (Batissa violacea var. celebensis, von Martens, 1897), 1897 di Sungai
Pohara Kendari Sulawesi Tenggara. Tesis. IPB.

Bahtiar. 2007. Konservasi Populasi Pokea (Batissa violacea var. celebensis von Martens, 1897), 1897 di Sungai Pohara Kendari Sulawesi Tenggara. Laporan Hibah Bersaing. DP2MDikti. Jakarta.

Bahtiar, Yulianda, F dan I. Setyobudiandi. 2008. Kajian Aspek Pertumbuhan Populasi Pokea (Batissa violacea var. celebensis, von Martens 1897) di Sungai Pohara Kendari Sulawesi Tenggara. Jurnal Ilmu-Ilmu Perairan dan Perikanan Indonesia. Jilid 15. 1: 1-5.

Bahtiar, 2012. Studi Bioekologi dan Dinamika Populasi Pokea (Batissa violacea var. celebensis von Martens, 1897) yang Tereksploitasi Sebagai Dasar Pengelolaan di Sungai Pohara Sulawesi Tenggara. Disertasi. IPB. Bogor.

Bahtiar, Emiyarti dan Nurgayah, W. 2014. Model Pengelolaan Spatial dan Temporal Sumberdaya Kerang Pokea yang Tereksploitasi (Batissa violacea var. celebensis, von Martens 1897) Berbasis Ekobiologi \& Dinamika Populasi dalam Penguatan Pangan Lokal di Sulawesi Tenggara. Laporan Hasil Penelitian SiNAS Ristek. Kemenristek. Kendari.

Bretos M. 1980. Age Determination in the Keyhole Limpet Fissurella crassa Lamark (Archaeogastropoda: Fissurellidae), Based on Shell Growth Rings. Biological Bulletin, 159: 606-612.

Efriyeldi., Bengen, D.G., Affandi, R., Prartono, T. 2012. Karakteristik Biologi Reproduksi Kerang Sepetang (Pharella acutidens) di Ekosistem 
Mangrove Dumai, Riau. Jurnal Perikanan Terubuk. 40(1). 36-44.

Gayanilo dan D. Pauly. 2002. The FAOICLARM. Stock Assessment Tools. (Fi-SAT Versi 2001). http:/www.FAO.org/fi/projects/fias.a sp.

Hasa, H. 2008. Pertumbuhan dan Tingkat Eksploitasi Populasi Kerang Hijau (P. viridis) di Perairan Desa Sorue Jaya. Kecamatan Soropia. Kabupaten Konawe. Sulawesi Tenggara. Skripsi. Fakultas Perikanan dan Ilmu Kelautan UHO. Kendari. 49 hal.

Hughes, R.N. and D.J. Roberts. 1980. Growth and reproductive rates of Littorina neritoides (L.) in North Wales. Journal of the Marine Biological Association of the United Kingdom, 60: 591-599.

King, M. 1997. Fisheries Biology. Assessment and Management. Fishing News Books. A Division of Blackwell Science Ltd. London. 341p.

Ledua, E., S.V. Matoto, Apisai, S and K. Jovesa. 1996. Freshwater Clam Resources Assesment of the $\mathrm{Ba}$ River. Fisheries Division. South Pasific Comision. New Caledonia. Suva. Fiji.

Narisimham, K.A. (1981) Dimensional relationships and growth of green mussel Perna viridis in Kakinada Bay. Indian Journal of Fisheries, 28: 240-248.

Natan, Y. 2009. Parameter Populasi Kerang Lumpur Tropis Anodontia edontula di Ekosistem Mangrove. Jurnal Biologi Indonesia. Fakultas Perikanan dan Ilmu Kelautan. Universitas Patimura. Ambon. 6(1):25-38.
Puteri, R.E. 2005. Analisis Populasi dan Habitat : Sebaran Ukuran dan Kematangan Gonad Kerang Lokan Batissa violacea Lamarck (1818) di Muara Sungai Batang Anai Padang Sumatera Barat. Tesis. Institut Pertanian Bogor.

Ramesha, M.M. and S. Thippeswamy. 2009. Allometry and Condition Index in the Freswater Bivalve Parreysia corrugate (Muller) From River Kempuhol, India. J. Asian Fisheries Science. 22:203-214.

Safaat, M.A. 2014. Studi Laju Tingkat Eksploitasi Kerang Kalandue (Polymesoda erosa) di Hutan Mangrove Teluk Kendari. Skripsi. Fakultas Perikanan dan Ilmu Kelautan UHO. Kendari. 46 hal.

Schweers, T., M. Wolff, V. Koch, and F.S. Duarte. 2006. Population Dynamics of Megapitaria squalida (Bivalvia: Veneridae) at Magdalena Bay, Baja California Sur, Mexico. Rev. Biol. Trop (Int. J). 54(3):1003-1017.

Setyobudiandi, I. 2004. Beberapa Aspek Biologi Reproduksi Kerang Hijau (Perna viridis Linnaeus, 1758) pada Kondisi Perairan Berbeda. Disertasi. Sekolah Pasca Sarjana. IPB. Bogor. Sousa, R., J.A. Antonio, J.A. Nogueira, M.B. Gaspar, C. Antunes, L. Guilhermino. 2008. Growth and Etremely High Production of the Non-Indigenous Invasive Species Corbicula fluminea (Muller, 1774): Possible Implications for Ecosystem Functioning. $J$. Estuarine, Coastal and Shelf Science. 80:289-295.

Sparre, P.dan S.C. Venema. 1999. Introduksi Pengkajian Stok Ikan Tropis. Badan Penelitian dan Pengembangan Perikanan. Terjemahan dari Introduction to 
Topical Fish Stock Assessment. FAO Fish Tech. Paper, 306(1):376p. Tamsar, 2012. Aspek Pertumbuhan Kerang Kalandue (Polymesoda erosa) di Perairan Hutan Mangrove Teluk Kendari Sulawesi Tenggara. Skripsi. Universitas Halu Oleo. Kendari.

Wibur, K.M. and G. Owen. 1964. Growth In: Physiology of Mollusca, (ed. K.M. Wilbur and C.M. Yonge). Vol. I;pp211-242. Academic Press, New York. 